\title{
Thioglycollate-elicited murine macrophages are cytotoxic to Mycoplasma arginini-infected YAC-1 tumor cells
}

\author{
F. Ribeiro-Dias ${ }^{1}$, M. Russo ${ }^{1}$, \\ F.R.F. Nascimento ${ }^{1}$, \\ J.A.M. Barbuto ${ }^{1}$, \\ J. Timenetsky² and S. Jancar ${ }^{1}$
}

Departamentos de ${ }^{1}$ mmunologia and $2 \mathrm{M}$ icrobiologia, Instituto de Ciências Biomédicas, Universidade de São Paulo, São Paulo, SP, Brasil

\section{Correspondence \\ S. Jancar \\ Departamento de Imunologia ICB, USP \\ Av. Prof. Lineu Prestes, 2415 \\ 05508-900 São Paulo, SP \\ Brasil \\ Fax: + 55-11-818-7224 \\ E-mail: sojancar@biomed.icb2.usp.br \\ Presented at the XIII Annual Meeting of the Federação de Sociedades de Biologia Experimental, Caxambu, MG, Brasil, August 26-29, 1998. \\ Research supported by FAPESP (No. 95/9336-1).}

Received April 15, 1998

Accepted August 10, 1998

\section{Abstract}

Macrophages are important components of natural immunity involved in inhibition of tumor growth and destruction of tumor cells. It is known that these cells can be activated for tumoricidal activity by lymphokines and bacterial products. We investigated whether YAC-1 tumor cells infected with Mycoplasma arginini stimulate nitric oxide (NO) release and macrophage cytotoxic activity. Thioglycollate-elicited macrophages from male BALB/c mice were co-cultured for $20 \mathrm{~h}$ with YAC-1 tumor cells infected or not with Mycoplasma arginini. The cytotoxic activity was evaluated by MTT assay and nitrite levels were determined with the Griess reagent. Thioglycollate-elicited macrophages co-cultured with noninfected YAC-1 cells showed low cytotoxic activity $(34.7 \pm 8.6 \%)$ and low production of $\mathrm{NO}(4.7 \pm 3.1$ $\mu \mathrm{M} \mathrm{NO}{ }_{2}^{-}$). These macrophages co-cultured with mycoplasma-infected YAC-1 cells showed significantly higher cytotoxic activity $(61.4 \pm 9.1 \% ; \mathrm{P}<0.05)$ and higher NO production $(48.5 \pm 13 \mu \mathrm{M}$ $\left.\mathrm{NO}_{2}^{-} ; \mathrm{P}<0.05\right)$. Addition of L-NAME $(10 \mathrm{mM})$, an inhibitor of NO synthesis, to these co-cultures reduced the cytotoxic activity to $37.4 \pm$ $2 \%(\mathrm{P}<0.05)$ and NO production to $3 \pm 4 \mu \mathrm{M} \mathrm{NO}_{2}{ }^{-}(\mathrm{P}<0.05)$. The present data show that Mycoplasma arginini is able to induce macrophage cytotoxic activity and that this activity is partially mediated by NO.

Macrophages are usually found in tumor infiltrates where they exert cytostatic/cytotoxic activities against tumor cells. The tumoricidal activity is enhanced by activation of macrophages with bacterial products or cytokines $(1,2)$. Recently nitric oxide (NO) has been indicated as a critical effector molecule for macrophage anti-tumor activity $(3,4)$. Macrophages can be induced to release NO upon stimulation with a variety of
Key words - Macrophages - Cytotoxicity

- Mycoplasma

- Tumor cells

- Nitric oxide stimuli such as bacterial products or cytokines $(3,5)$. More recently it has been reported that mycoplasma-treated macrophages release large amounts of NO (6).

YAC-1 tumor cells have been classically used as targets for natural killer (NK) cells. Resident macrophages do not present antiYAC-1 activity, but lymphokine-activated macrophages are able to kill YAC-1 cells (7). The mechanism by which lymphokine- 
Figure 1 - Mycoplasma argininiinfected YAC-1 tumor cells induce macrophage cytotoxic activity and nitric oxide production. Thioglycollate-elicited peritoneal macrophages $\left(2 \times 10^{5}\right)$ were cocultured with YAC-1 tumor cells infected or not with Mycoplasma arginini $\left(5 \times 10^{4}\right)$ for 20 h. Nitrite concentration was measured by the Griess reaction and macrophage cytotoxicity by the MTT assay. Results are reported as means $\pm \mathrm{SD}$ for $\mathrm{N}=4$. $* \mathrm{P}<0.05$ (Student t-test).

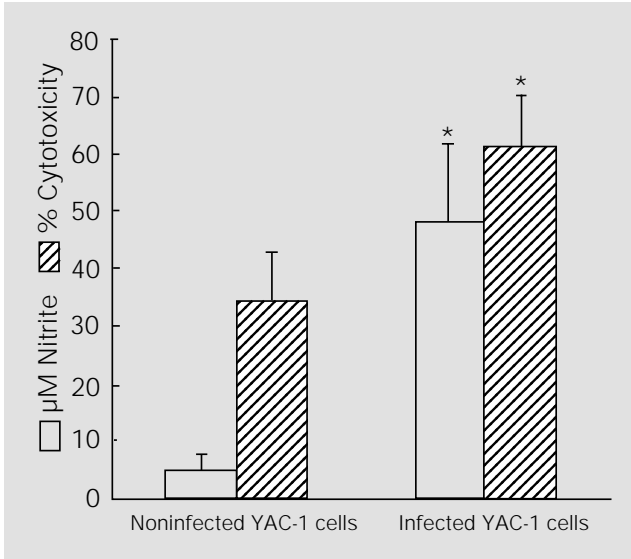

activated macrophages kill YAC-1 cells remains unsettled.

Based on these observations, we asked whether mycoplasma-infected YAC-1 tumor cells could stimulate macrophages to release $\mathrm{NO}$ and if this molecule, in turn, will lyse the infected YAC-1 cells.

Six- to eight-week-old male BALB/c mice were used throughout the experiments. Macrophages were harvested by lavage of the peritoneal cavity with $5 \mathrm{ml}$ of phosphate buffered saline (PBS) 5 days after intraperitoneal injection of $1 \mathrm{ml}$ of $3 \%$ thioglycollate medium (Gibco, Gaithersburg, MD). The cells were centrifuged and adjusted to $2 \mathrm{x}$ $10^{6}$ cells/ml in RPMI 1640 medium (Sigma Chemical Co., St. Louis, MO) supplemented with $10 \mathrm{mM}$ HEPES, $11 \mathrm{mM}$ sodium bicarbonate, $2 \mathrm{mM} \mathrm{L}$-glutamine, $100 \mathrm{U} / \mathrm{ml}$ penicillin, $100 \mu \mathrm{g} / \mathrm{ml}$ streptomycin and $5 \%$ fetal bovine serum. The cell suspensions were plated $(100 \mu \mathrm{l} /$ well) onto 96-well flat-bottomed plates (Corning, New York, NY) and incubated for $2.5 \mathrm{~h}$ for adherence in a humidified atmosphere with $5 \% \mathrm{CO}_{2}$ at $37^{\circ} \mathrm{C}$. The nonadherent cells were removed by washing the wells with PBS. The adherent cells were $80-90 \%$ macrophages as judged by neutral red uptake.

Mycoplasma-free YAC-1 tumor cells were cultured with supernatants from $\mathrm{Myco}$ plasma arginini-infected cells (20\% v/v) in an antibiotic-free medium. Infection was confirmed by culture of supernatants in SP4 medium (8). The infected cells were maintained in complete medium. For cytotoxicity assays and induction of NO release, aliquots of tumor cell cultures were centrifuged, washed, resuspended in complete medium and adjusted to $5 \times 10^{5}$ cells $/ \mathrm{ml}$. Tumor cell suspensions (used as target cells) were added to macrophage cultures (effector cells) at a 4:1 effector to target (E:T) ratio. Effector and target cells (at the same cell number/ well) were separately incubated in complete medium $(100 \mu \mathrm{l} /$ well $)$ to establish control absorbance at $540 \mathrm{~nm}$. The plates were incubated for $20 \mathrm{~h}$ in $5 \% \mathrm{CO}_{2}$ in a humidified atmosphere for cytotoxicity and NO release assays.

Macrophage anti-YAC-1 activity was evaluated by the MTT (3-(4,5-dimethylthiazol-2yl)-2,5-diphenyltetrazolium bromide; Sigma) assay as described by Ferrari et al. (9). Briefly, $10 \mu \mathrm{l}$ of MTT ( $5 \mathrm{mg} / \mathrm{ml}$ in PBS) was added to wells and the plates were incubated for $3 \mathrm{~h}$. After this, $100 \mu \mathrm{l}$ of $10 \%$ SDS in $0.01 \mathrm{~N} \mathrm{HCl}$ was added in order to dissolve the formazan crystals generated by MTT reduction by living cells. The plates were incubated overnight and the absorbance was read at $540 \mathrm{~nm}$ in a microplate Labsystem Multiskan MS reader. Percent cytotoxicity was determined by the formula: \% cytotoxicity $=1-[($ absorbance at $540 \mathrm{~nm}$ of effector + target cells) - (absorbance at $540 \mathrm{~nm}$ of effector cells)]/[absorbance at $540 \mathrm{~nm}$ of target cells] x 100 .

NO release was determined by the standard Griess reaction as follows: $50 \mu \mathrm{l}$ of test solutions was added to 96-well flat-bottomed plates containing $50 \mu \mathrm{l} /$ well of Griess reagent $(1 \%$ sulfanilamide $/ 0.1 \% \mathrm{~N}-1$-naphthylethylene diamine dihydrochloride/2.5\% $\mathrm{H}_{3} \mathrm{PO}_{4}$ ). After $10 \mathrm{~min}$ at room temperature the absorbance of each well was measured in a Dynatech MR5000 microplate reader at $540 \mathrm{~nm}$ with a $620-\mathrm{nm}$ reference filter and the nitrite concentration was determined from a sodium nitrite standard curve.

To prevent NO release we added $10 \mathrm{mM}$ 
L-NAME $\left(\mathrm{N}^{\omega}{ }^{\omega}\right.$ - -arginine methyl ester; Sigma), an inhibitor of NO synthesis to the co-cultures. This concentration of L-NAME did not affect the viability of macrophages or tumor cells as evaluated by the MTT assay.

Initially we compared NO production in co-cultures of thioglycollate-elicited macrophages with YAC-1 cells infected or not with mycoplasma. As shown in Figure 1, macrophages co-cultured with mycoplasmafree YAC-1 cells produced very low levels of $\mathrm{NO}\left(4.7 \pm 3.1 \mu \mathrm{M} \mathrm{NO}_{2}^{-}\right)$. Conversely, high levels of $\mathrm{NO}\left(48.5 \pm 13 \mu \mathrm{M}\right.$ of $\left.\mathrm{NO}_{2}^{-}\right)$ were detected in co-cultures with mycoplasma-infected YAC-1 cells. Figure 1 also shows that thioglycollate-elicited macrophages co-cultured with mycoplasma-free YAC1 cells exhibited low cytotoxic activity (34.7 $\pm 8.6 \%$ ). In contrast, macrophage cytotoxic activity increased significantly when tested against Mycoplasma arginini-infected YAC1 cells $(61.4 \pm 9.1 \%, \mathrm{P}<0.05)$. Next, we asked whether inhibition of NO production by L-NAME would affect macrophage cytotoxicity. As shown in Figure 2, addition of $10 \mathrm{mM}$ L-NAME to macrophage co-cultures with mycoplasma-infected YAC-1 cells almost completely inhibited NO release when compared with untreated co-cultures (51.3 \pm 3 vs $3 \pm 4 \mu \mathrm{M} \mathrm{NO}_{2}^{-}$). Most importantly, inhibition of $\mathrm{NO}$ production was paralleled by a significant decrease in macrophage cytotoxicity $(64.3 \pm 4$ vs $37.4 \pm 2 \%)$.

Our results suggest that YAC-1 cells infected with Mycoplasma arginini stimulate macrophage NO production. In turn, NO exerts a cytotoxic activity against these tumor cells. However, it appears that YAC-1 cell killing does not rely entirely on NO release. This is documented in experiments where NO production was totally inhibited but significant cytotoxicity was still present $(50 \%)$. Thus, it remains to be determined

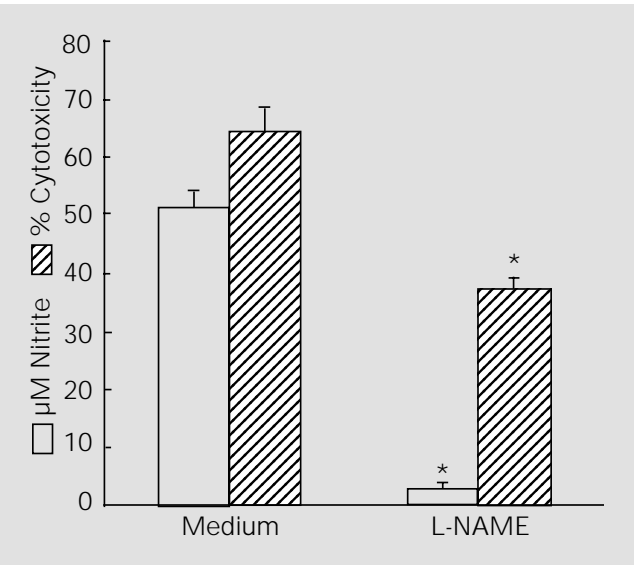

Figure 2 - Macrophage cytotoxic activity against Mycoplasma arginini-infected YAC-1 tumor cells is partially mediated by nitric oxide. Thioglycollate-elicited macrophages $\left(2 \times 10^{5}\right)$ were cocultured with Mycoplasma arginini-infected YAC-1 tumor cells $\left(5 \times 10^{4}\right)$ in the presence or absence of $10 \mathrm{mM}$ L-NAME for 20 h. Nitrite concentration was measured by the Griess reaction and macrophage cytotoxicity by the MTT assay. Results are reported as means \pm SD for $\mathrm{N}=4$. $* \mathrm{P}<0.05$ (Student $\mathrm{t}$-test).

whether macrophages are able to kill YAC-1 cells by an NO-independent mechanism or contaminating NK cells are operating in this situation. Mycoplasma-induced macrophage NO production has been previously documented. For example, Mühlradt \& Schade (10) found that murine resident peritoneal macrophages primed with interferon $\gamma($ IFN $\gamma)$ released significant amounts of NO, when stimulated with a product extracted from Mycoplasma fermentans. Similarly, Yang et al. (11) showed that Mycoplasma argininiinfected L5178Y, a T-cell lymphoma, produces a triggering factor for $\mathrm{NO}$ production by thioglycollate-elicited macrophages primed with IFN $\gamma$. Interestingly, in our experiments Mycoplasma arginini-infected tumor cells were able to induce NO production in thioglycollate-elicited macrophages in the absence of exogenous cytokines.

Since mycoplasmas are potentially associated with animal and human diseases including immunodeficiencies (12) it is possible that macrophage activation induced by mycoplasma may contribute to clinical manifestations of these disorders. Finally, mycoplasma frequently contaminates cell cultures (13), and thus may alter macrophage or other cell functions assayed in vitro. 


\section{References}

1. Lemaire G, Barratt G, Drapier J C, GrandPerret T, Lepoivre M, Tenu J P \& Petit J F (1986). Activation of macrophages to tumour cytotoxicity by bacterial products. Annales de L'Institut Pasteur/Immunologie, 137C: 218-223.

2. Stuehr DJ \& Marletta MA (1987). Induction of nitrite/nitrate synthesis in murine macrophages by BCG infection, lymphokines, or interferon- $\gamma$. J ournal of Immunology, 139: 518-525.

3. Hibbs J B, Taintor RR, Vavrin $Z \&$ Rachlin EM (1988). Nitric oxide: A cytotoxic activated macrophage effector molecule. Biochemical and Biophysical Research Communications, 157: 87-94.

4. Klostergaard J , Leroux ME \& Hung M-C (1991). Cellular models of macrophage tumoricidal effector mechanisms in vitro. Characterization of cytolytic responses to tumor necrosis factor and nitric oxide pathways in vitro. J ournal of Immunology, 147: 2802-2808.

5. Lorsbach RB \& Russell SW (1992). A specific sequence of stimulation is required to induce synthesis of the antimicrobial molecule nitric oxide by mouse macrophages. Infection and Immunity, 60: 21332135.

6. Mühlradt PF \& Frisch M (1994). Purification and partial biochemical characterization of a Mycoplasma fermentans-derived substance that activates macrophages to release nitric oxide, tumor necrosis factor, and interleukin-6. Infection and Immunity, 62: 3801-3807.

7. Roder J C, Lohmann-Matthes $M-L$, Domzig W, Kiessling R \& Haller O (1979). A functional comparison of tumor cell killing by activated macrophages and natural killer cells. European J ournal of Immunology, 9: 283-288.

8. Tully J G (1995). Culture medium formulation for primary isolation and maintenance of Mollicutes. In: Razin S \& Tully J G (Editors), Molecular and Diagnostic Procedures in Mycoplasmology. Academic Press, New York, 33-40.

9. Ferrari $M$, Fornasiero $M C \&$ Isetta $A M$ (1990). MTT colorimetric assay for testing macrophage cytotoxic activity in vitro. J ournal of Immunological Methods, 131: 165-172.

10. Mühlradt PF \& Schade U (1991). MDHM a macrophage-stimulatory product of $\mathrm{My}$ coplasma fermentans, leads to in vitro interleukin-1 (IL-1), IL-6, tumor necrosis factor, and prostaglandin production and is pyrogenic in rabbits. Infection and Immunity, 59: 3969-3974.

11. Yang G, Coffman FD \& Wheelock EF (1994). Characterization and purification of a macrophage-triggering factor produced in Mycoplasma arginini-infected L5178Y cell cultures. J ournal of Immunology, 153: 2579-2591.

12. Yechouron A, Lefebvre J, Robson HG, Rose DL \& Tully J G (1992). Fatal septicemia due to Mycoplasma arginini: a new human zoonosis. Clinical Infectious Diseases, 15: 434-438.

13. Ruuth E \& Praz F (1989). Interactions between mycoplasmas and the immune system. Immunological Reviews, 112: 133160. 